\title{
BARRIERS OF EFFECTIVE EDUCATION AND EMPLOYMENT FACING SAUDI WOMEN
}

Dalal Ammash Mubark AlDossary

Prince Mohammad Bin Fahd University, Alkhobar, Saudi Arabia

Email: dalal.dossary@hotmail.com

\begin{abstract}
The purpose of the research is to discuss the major barriers that affect the education and career for females in Saudi Arabia. The study also discusses the role of the privates sector in education.

The research is based on secondary information that is collected from various sources such as articles, book and articles form journals. In addition, an exploratory research method, using a questionnaire is the basic research design for this study and it represents the primary data. 150 questionnaires were distributed. The number of questionnaires collected after completing the answers was 102. The data were coded and tabulated for analysis by using MS EXCEL.

Saudi Arabian families and Saudi society has accepted the changes to look for better and higher education for females. This won't be completed without matching jobs available that is associated with the type of education. The Saudization program is not effective.
\end{abstract}

Keywords: Saudi Arabia, Female Education, Private Sector

\section{Introduction}

The Saudi government has prioritized providing free education to all citizens. The government has successfully built a strong educational infrastructure starting from elementary school to higher education.

Because of the strategic importance of the education in Saudi Arabia, the government has used a large budget dedicated for educational purposes. This includes the building of schools, colleges and universities. Looney, (2004) stated that the educational system which in coordination with the private sector should reduce the high unemployment rates in order to reduce the dependence of foreign workers.

Al-Munajjed, (2010) stated that:

Although over 90 percent of Saudi women actively participating in the workforce hold a secondary qualification or a university degree, simply getting a degree does not guarantee employment: 78.3 percent of unemployed women are university graduates, and more than 1,00o have a doctorate degree. By contrast, 76 percent of unemployed men have only a secondary education or less. In 2007, 93 percent of all female university graduates specialized in education and humanities, while a shortage of jobs in those fields has resulted in Saudis seeking work abroad. More than 300 Saudi female graduates have already accepted teaching jobs in Kuwait, Qatar, and Bahrain.” 
Al-Munajjed, (2010) stated that it is true that the percentage of illiterate women is $30 \%$ but there are more than one million women unable to find a career opportunity because of low education or lack of skill. Seeking knowledge is mandatory for each Muslim. The principles of education formulated by the Higher Committee of Educational Policy include the responsibility to: (1) strengthen faith in God and Islam and in Mohammed; (2) foster a holistic, Islamic concept of the universe; (3) emphasize that life is a stage of work and production to invests full understanding of faith and eternal life; (4) proclaim the message of Mohammed; (5) instill Islamic ideals; (6) engender faith in human dignity; (7) reinforce the duty of each Muslim to see education and the duty of the state to provide education in it various stages within the state's capacity and resources; (8) incorporate religious education and maintain Islamic culture at all educational levels; (9) integrate Islamic orientation in sciences and knowledge in the curricula and teaching; (10) stimulate human knowledge through Islam to raise the nation's standard of living; (11) foster fundamental beliefs; and (12) teach the importance of Saudi history and the preservation of Islam.

\section{Objective of the Study}

The purpose of the study is to discuss the major changes in the Saudi society that affects the education process. In addition to that, the study also discusses the obstacles that face Saudi women in education and career.

\section{Significance of the Study}

The significance of the study is that it focuses on a descriptive approach to demonstrate the current situation of women education and its effect on facilitating their chances to take a considerable role in the labor market, and suggest steps aiming towards promoting women's advancement within the labor market.

\section{Research Questions}

The study has objectives. These objectives are 1- What are the major changes in the Saudi society that affects the education process?

2- What are the types of obstacles that face women in education and career?

\section{Hypotheses}

There is one hypotheses that is tested in this research

H: Saudization program is not effective

\section{Review of the literature}

\subsection{Historical Overview}

The issues of women in Arab culture should always be handled with care because of the sensitivity of this issue. Hamdan, (2005) mentioned that "In recent years, no sector of Saudi society has been subject to more debates and discussions than the women's sector and their role in the development process." It is not only education and career but also basic and luxuries needs are included too. However, education has a bigger role in Saudi Arabia.

Saudi Arabia is a country that depends on oil to support its economy. Oil was discovered in the 1930s and the changes started to take place in the 1970s (Hamdan, 2005). Education for both males and females is one of the changes that took place and that were part of the high-income 
effects (Yamani, 1996). This process changed the life style of the society especially for those who have worked for companies like Saudi Aramco (Yamani, 1996). From another point of view, events like the Iranian revolution and the takeover of Makkah that took place in 1979 gave the religious wing in Saudi Arabia more influence (Hamdan, 2005). The forces of the modernization and the religious forces affected the women's position in education and career development to a great extent.

The final effect that influences the educational system in Saudi Arabia and had a major impact of the influence of the religious side was the events of September 112001 (Rugh, 2002). The fact that out of 19 terrorists, there were 15 from Saudi Arabia had meant there was pressure to change the educational system. According to Rugh, (2002) "...some American editorial writers have pointed accusing fingers at the Saudi education system as having fostered an attitude of intolerance of non-Muslims and a hatred of Americans."

\subsection{Barriers of Women Education and Professions}

There are many limitations that face females in education and in career. Although religion was used to limit the opportunities of females, Quran made clear that women and men are equal (Gender Equality in Islam, 1995). In addition, Baki (2004) stated that one of the problems that face women is that the private sector is not participating on designing the education system and as a result of that, there is a big gap between the two. Another problem is the Saudization program itself. Viviano (2003) stated that this program stopped Saudi males and females from developing their skills like expatriates do because they depend on the law to be hired.

\section{3 Development of Female Education and Career}

The females' education in Saudi Arabia was under the management of the Department of Regions Guidance (Hamdan, 2005). The restriction made by this management was benefiting the education of females in which more of them had higher education even more than men (Cordesman, 2003). Because of many restrictions on women career in Saudi Arabia, women were seeking better and higher education (Baki, 2004). This is very clear from the number of males and females graduates in which females graduates are higher than males.

However, the situation for career is very bad for females. For example, no matter how educated and talented the female is, she is placed under males (Smith, 1987). This picture is not only in Saudi Arabia but almost in all Arab and Islamic countries (Hamdan, 2005).

\subsection{Education in Saudi Arabia}

As a result of the need for reforming the educational system and to meet the strategic goals of the country, there were many results. The funds were allocated from the five-year development plan in which billions were reserved for the educational sector. As a result of the increase of the number of schools for males and females, the number of student increased (Saudi Arabian Monetary Agency, 2010). In 2010, there were 6,137,186 students of which there were 2,973,412 (Saudi Arabian Monetary Agency, 2010). The female students had a percentage of $48.5 \%$ of the total number of students (Saudi Arabian Monetary Agency, 2010).

The increase in number of student means an increase in teachers and schools in Saudi Arabia. In 2010, the number of schools was 26,268 and of these there were 12,975 for females (Saudi Arabian Monetary Agency, 2010). In addition, the number of teachers reached 417,459 (Saudi 
Arabian Monetary Agency, 2010). The number of female teachers was 2010,004 which is more than $50 \%$ of the total number of teachers in Saudi Arabia (Saudi Arabian Monetary Agency, 2010).

\section{5 Unemployment Rate in the Kingdom}

The Saudi Arabian Monetary Agency published the number of job seekers in Saudi Arabia. The table below indicates that the number of seekers increase every year because the education system graduates new students every year. The number increase from 2007 to 2009 as respectively as follow. In 2007 it was 156,372 and in 2009, it became 111,865 persons (Saudi Arabian Monetary Agency, 2010).

\begin{tabular}{lcccc}
\hline & Table 1 : Number of Job-Seekers by Region & \\
\hline Riyadh & $\mathbf{2 0 0 7}$ & $\mathbf{2 0 0 8}$ & $\mathbf{2 0 0 9}$ & Percentage Ratio \\
\hline Makkah & 29.608 & 27.780 & 23.527 & 21.0 \\
\hline Al-Madinah & 24.671 & 19.777 & 14.591 & 13.0 \\
\hline Al-Qassim & 5.169 & 3.305 & 3.801 & 3.4 \\
\hline Eastern & 3.906 & 3.947 & 4.434 & 4.0 \\
\hline Asir & 62.832 & 55.295 & 43.808 & 39.2 \\
\hline Ha'll & 16.632 & 22.583 & 9.010 & 8.1 \\
\hline Tabuk & 1.840 & 605 & 785 & 0.7 \\
\hline Al-Bahah & 1.797 & 1.821 & 1.918 & 1.7 \\
\hline Northern Border & 1.558 & 1.583 & 1.027 & 0.9 \\
\hline Al-Jawf & 1.120 & 1431 & 11.58 & 1.0 \\
\hline Jazan & 16 & 1680 & 1.77 & 0.2 \\
\hline Najran & 5.302 & 5.724 & 4.254 & 5.6 \\
\hline Total & 1.921 & 1.666 & 1.375 & 1.2 \\
\hline
\end{tabular}

Source: (Saudi Arabian Monetary Agency, 2010)

The largest segment of people who are looking for jobs are the ones who are 20-24 (Saudi Arabian Monetary Agency, 2010). People with 25-34 years old are the second largest group who are looking for jobs in the Saudi local market (Saudi Arabian Monetary Agency, 2010). The number of job seekers based on their age is shown in the table below

Table 2: Number of Job-Seekers by Age

\begin{tabular}{ccccc}
\hline Age & $\mathbf{2 0 0 7}$ & $\mathbf{2 0 0 8}$ & $\mathbf{2 0 0 9}$ & Percentage Ratio \\
\hline Less than 20 years & 35.225 & 19.366 & 13.586 & 12.1 \\
\hline 20 - 24 years & 68.497 & 66.553 & 47.702 & 42.6 \\
\hline
\end{tabular}




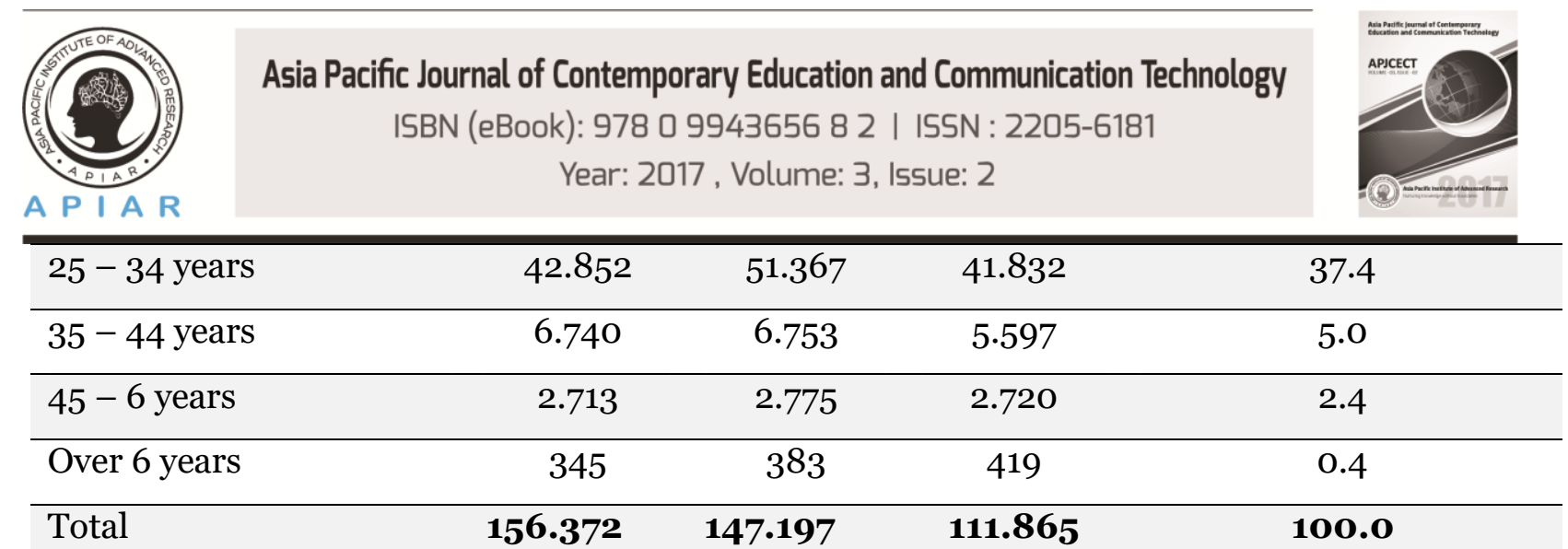

Source: (Saudi Arabian Monetary Agency, 2010)

\section{Methodology}

The collections of the data are a major tool that determines the effectiveness of the research. Therefore, the methodology used is a critical decision to be taken. Because of the importance of the methodology, it has been chosen in this research to be a mix between quantitative and qualitative. The combination will be a result of the use of a survey with observation to benefit from the advantages of both methodologies.

\section{1 Research Design}

The research is based on secondary information collected from various sources such as articles, books and research papers. In addition, an exploratory research method, using a questionnaire is the basic research design for this study and it represents the primary data.

\subsection{Data Collection}

Secondary data relevant to the study was gathered from various journals, research studies and articles. The self-administered questionnaire formed the primary data collection. The survey was distributed to females who are working in banks and companies that their administration accepted the distribution of the questionnaire. The number of questionnaires that were distributed was 150 . The number of questionnaires collected after completing the answers were 102. The ratio from distributed to collected questionnaire is $102 / 150=68 \%$ is considered a high ratio. After collecting the data, the information will be analyzed through a process of eliminate mistakes, legibility and inconsistencies.

\section{$7 \cdot 3$ Content validity}

A group of two experts have been assembled to rate the validity of the survey. These two persons are:

1- Kholod Al-Rabia

2- Hana'a Al-Sayarai

This group after reading the survey was asked to assess it answering this question:

I find the questions of the survey:

A) Valid

B) Not Valid 


\section{Asia Pacific Journal of Contemporary Education and Communication Technology \\ ISBN (eBook): 9780994365682 | ISSN : 2205-6181 \\ Year: 2017 , Volume: 3, Issue: 2}

The result is as the following:

I find the question of the survey

\begin{tabular}{lc}
\hline 1- Kholod Al-Rabia & A \\
\hline 2- Hana'a Al-Sayarai & A \\
\hline
\end{tabular}

Content Validity Ratio (CVR) $=[(\mathrm{E}-(\mathrm{N} / 2)) /(\mathrm{N} / 2)]$

Where

$\mathrm{N}=$ is the number of people assessing the survey $=2$

$\mathrm{E}=$ Highest rate $=4$

$\operatorname{CVR}=[(4-(2 / 2)) /(2 / 2)]$

$\mathrm{CVR}=[(3-2) / 1)]$

$\mathrm{CVR}=2 / 1$

$\mathrm{CVR}=2$

7.4 Pilot Test and Reliability

The survey was distributed to test the reliability of the questions. A number of 5 participants have received the survey to check for suitability and their understandability of the questions and the clearness of the meaning.

The same procedures that have been done for distributing and collecting the questionnaire were used in the pilot test.

\section{Data Analysis}

The data was coded and tabulated for analysis by using MS EXCEL. The types of statistical tests that have been used are frequencies, and ANOVA. The same software was also used for graphical representation.

\subsection{Result}

\section{Introduction}

The purpose of the study is to discuss the major changes in the Saudi society that affects the education process. In addition to that, the study also discusses the obstacles that face Saudi women in education and career.

\section{Data Analysis}

\section{1- Data Analysis}

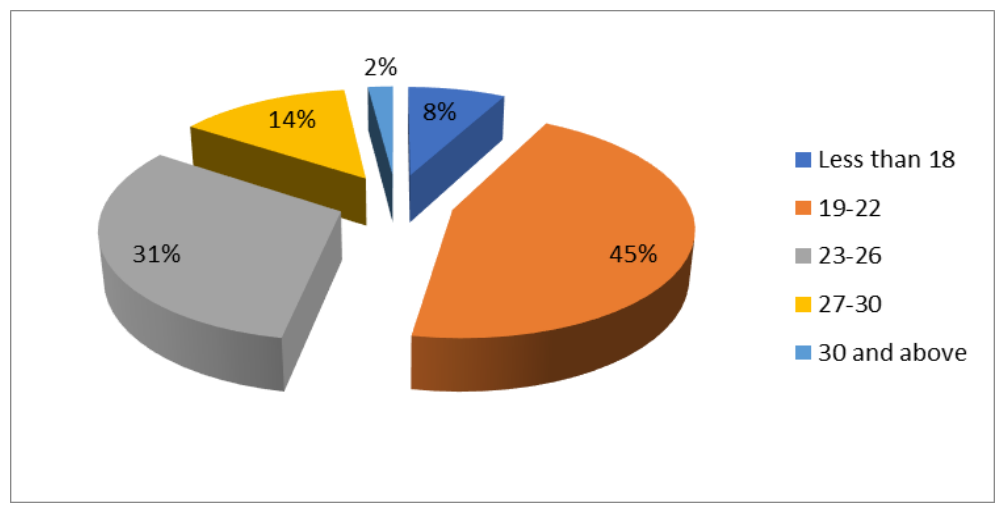

Fig 1: Age 
The largest age segment was $45 \%$ for those who are 19-22 and the smallest age segment was $2 \%$ for those who are older than 30 .

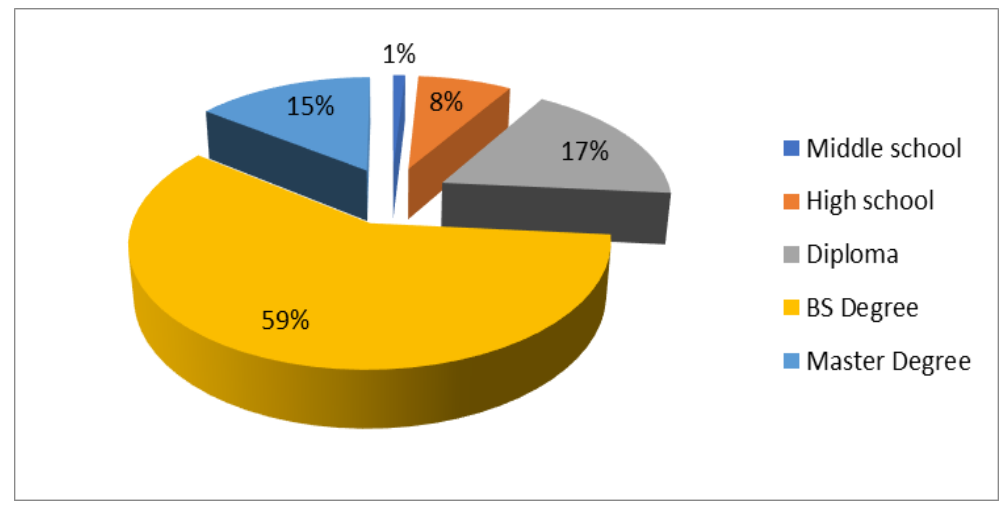

Fig 2: Education

Bs holders represent $59 \%$ of the survey and the smallest education segment was middle school with a percentage of $1 \%$.

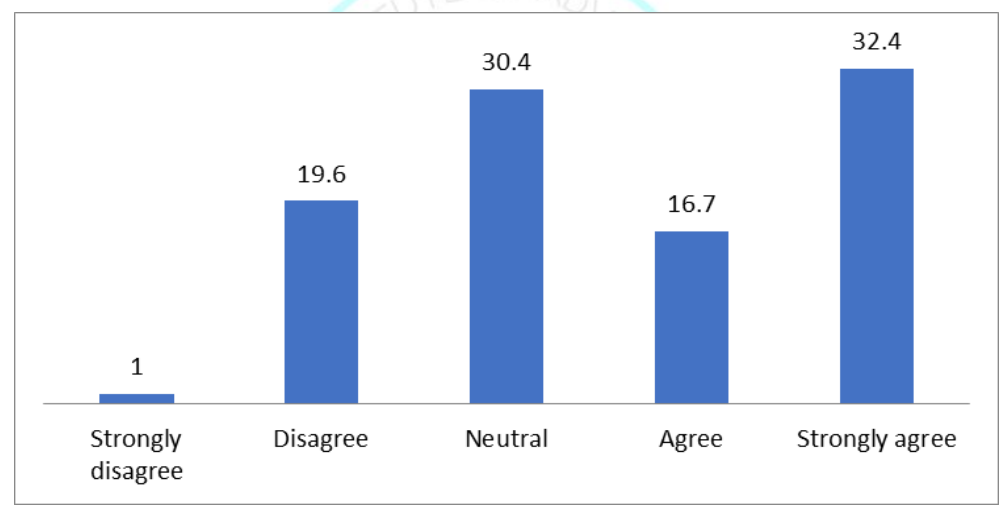

Fig 3: Transportations is one of the barriers in education and working

Respondents who strongly disagreed and disagreed with the statement "transportations is one of the barriers in education and working" were $20.6 \%$ while those who agreed and strongly agreed were $49.15 \%$ 


\section{Asia Pacific Journal of Contemporary Education and Communication Technology \\ ISBN (eBook): 9780994365682 | ISSN : 2205-6181 \\ Year: 2017 , Volume: 3, Issue: 2}

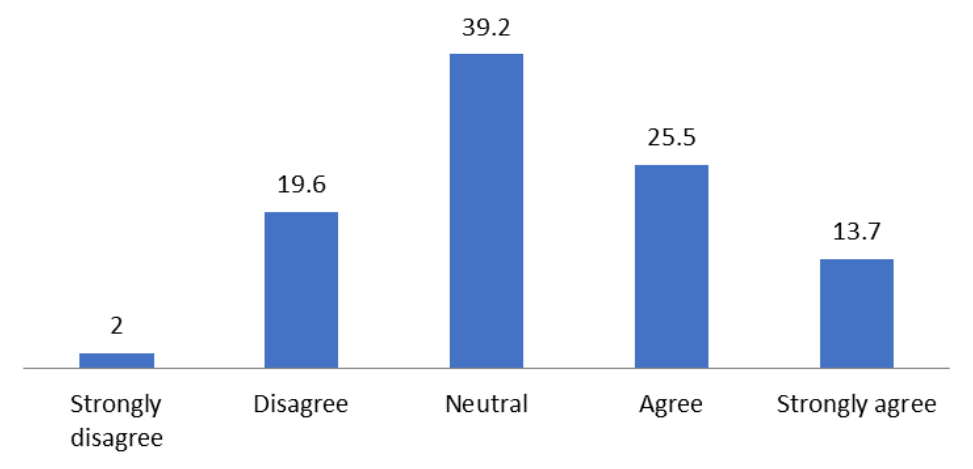

Fig 4: My family supports me in education

Respondents who strongly disagreed and disagreed with the statement "My family supports me in education" were $21.6 \%$ while those who agreed and strongly agreed were $39.2 \%$

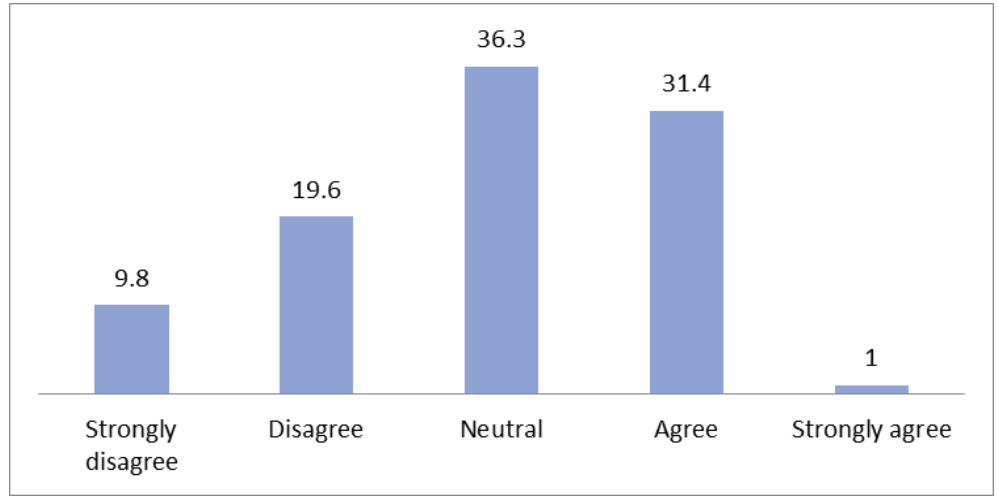

Fig 5: The society looks at working women positively

Respondents who strongly disagreed and disagreed with the statement "I need the help of my family for finding a job" were $29.4 \%$ while those who agreed and strongly agreed were $32.4 \%$

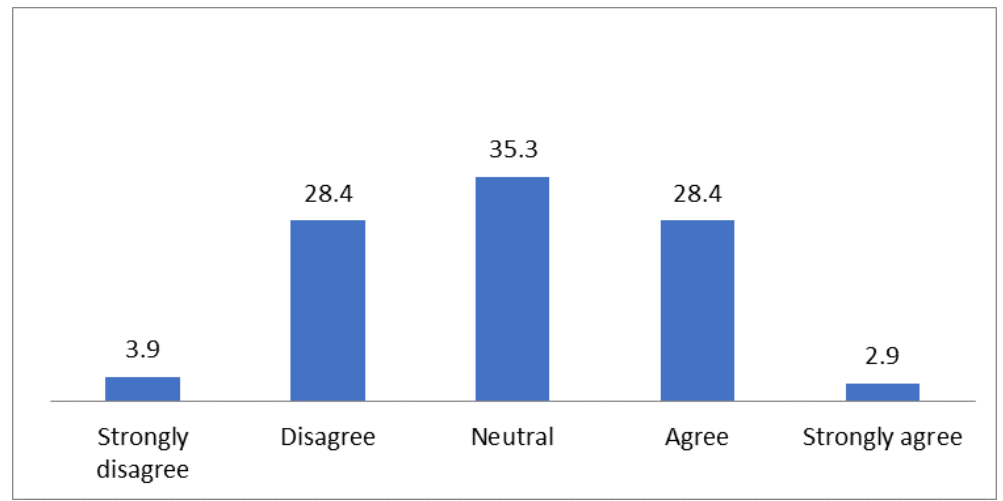

Fig6: There are many good examples of successful women in their education 


\section{Asia Pacific Journal of Contemporary Education and Communication Technology \\ ISBN (eBook): 9780994365682 I ISSN : 2205-6181 \\ Year: 2017 , Volume: 3, Issue: 2}

A P I A R

Respondents who strongly disagreed and disagreed with the statement "There are many good examples of successful women in their education" were $32.3 \%$ while those who agreed and strongly agreed were $31.3 \%$

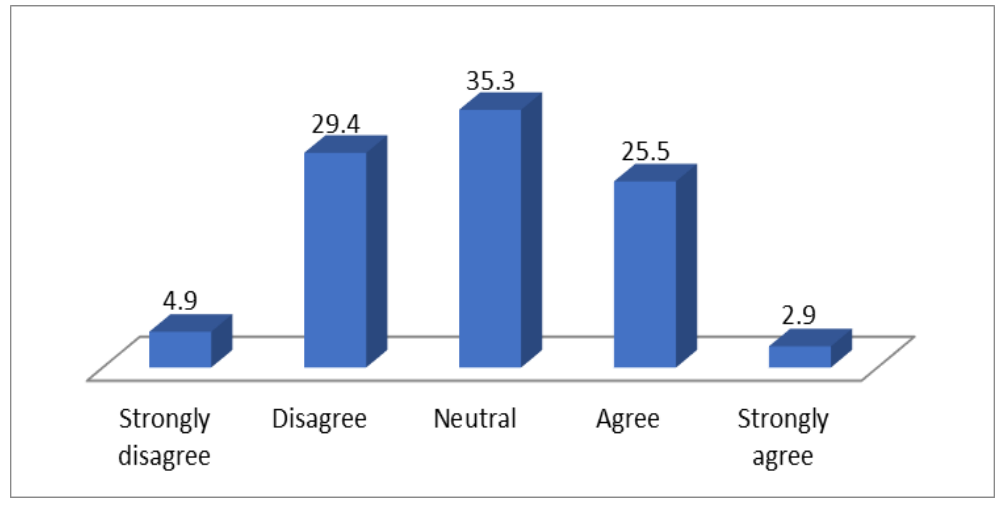

Fig 7: There is no gap between education and work requirements

Respondents who strongly disagreed and disagreed with the statement "There is no gap between education and work requirements" were $34.3 \%$ while those who strongly agreed and agreed were $28.4 \%$

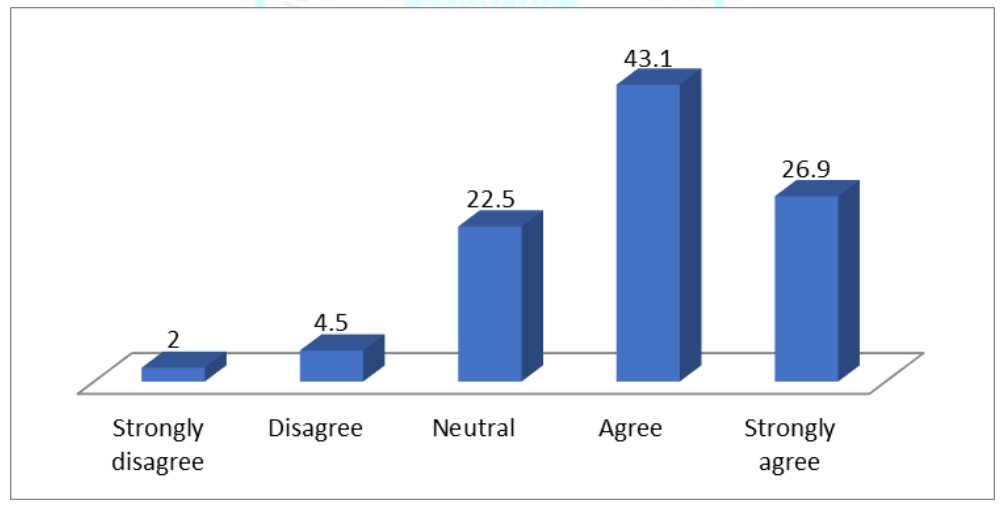

Fig 8: The major reason for completing my education is to find a suitable job

Respondents who strongly disagreed and disagreed with the statement "The major reason for completing my education is to find a suitable job" were $6.5 \%$ while those who strongly agreed and agreed were $70 \%$ 


\section{Asia Pacific Journal of Contemporary Education and Communication Technology \\ ISBN (eBook): 9780994365682 | ISSN : 2205-6181 \\ Year: 2017 , Volume: 3, Issue: 2}

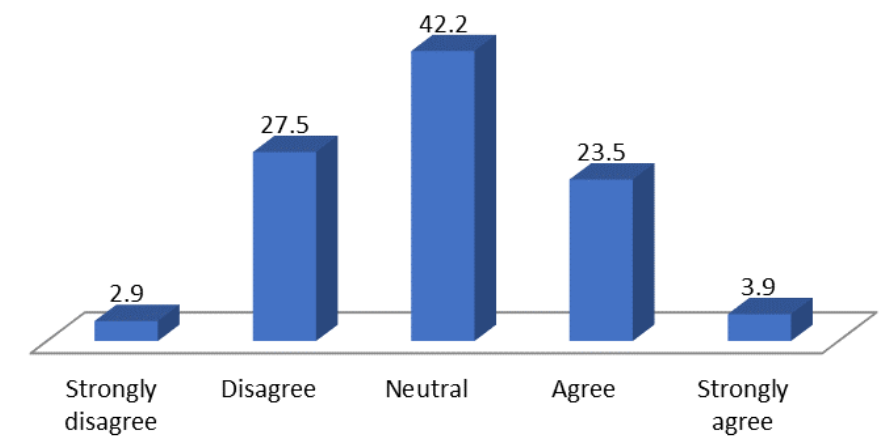

Fig 9: There are many types of majors that I can study

Respondents who strongly disagreed and disagreed with the statement "There are many types of majors that I can study" were 30.4\% while those who strongly agreed and agreed were $27.4 \%$

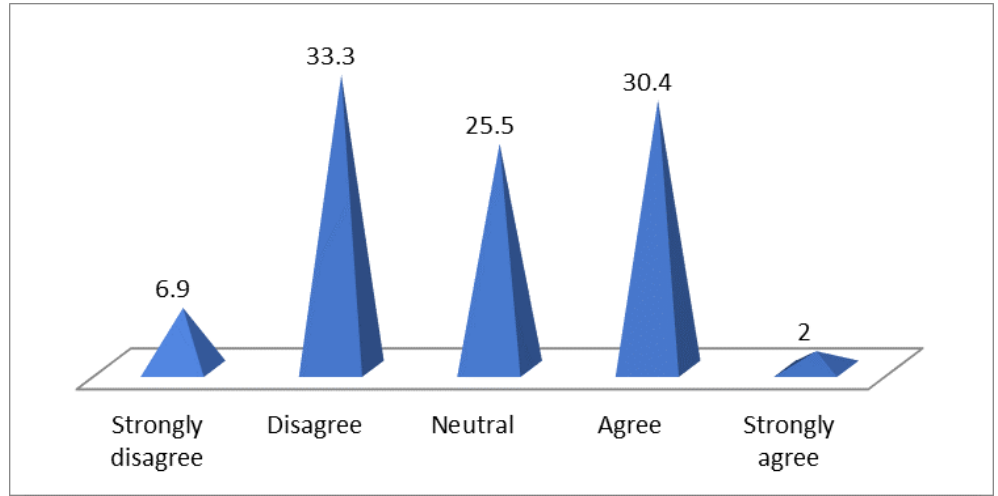

Fig 10: Saudization program is effective

Respondents who strongly disagreed and disagreed with the statement "Saudization program is effective" were $40.2 \%$ while those who strongly agreed and agreed were $32.4 \%$

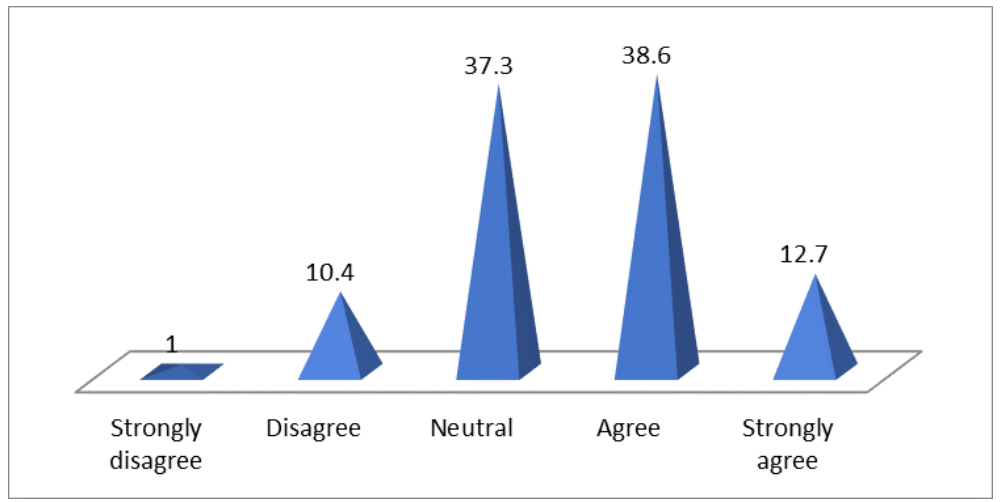

0
0
0
0
0

Fig 11: The government must issue new laws regarding employment of Saudi females 


\section{Asia Pacific Journal of Contemporary Education and Communication Technology \\ ISBN (eBook): 9780994365682 | ISSN : 2205-6181 \\ Year: 2017, Volume: 3, Issue: 2}

A P I A R

Respondents who strongly disagreed and disagreed with the statement "The government must issue new laws regarding employment of Saudi females" were 10.4\% while those who strongly agreed and agreed were $51.3 \% \%$

\subsection{Testing of Hypotheses}

Ho: Saudization program is not effective

Table 3: ANOVA

\begin{tabular}{lcccccc}
\hline & Sum of & df & Mean Square & F & $\begin{array}{c}\text { Si } \\
\text { Squares }\end{array}$ & \\
\hline $\begin{array}{l}\text { Saudization program } \\
\text { is not effective. }\end{array}$ & $\begin{array}{c}\text { Between } \\
\text { Groups }\end{array}$ & 2.524 & 4 & 0.631 & 0.612 & 0.655 \\
\hline & Within Groups & 97.689 & 95 & 1.031 & & \\
\hline & Total & 100.510 & 99 & & & \\
\hline
\end{tabular}

It is not statistically significance because the significance level of the ANOVA greater than the alpha (0.655>.05). The Ho is not rejected and this implies that Saudization program is not effective .

\section{Discussion}

The segment which was surveyed are Saudi females from different organizations with ages of $45 \%$ between 19 and 22 as the largest segment and the smallest segment was $2 \%$ for those who are older than 30. Most of them are BS Degree holders with a percentage of $59 \%$ and Diploma with a percentage of $17 \%$. Most of the segment is employees with a percentage of $39 \%$ and the second largest segment is the position of supervisor $27 \%$

The survey shows that transportation is a problem for both education and career. This is true when knowing that most of the respondents are coming from families with low financial status. From the survey, the society has accepted healthy changes and it accepted great improvements in areas of female education and work. In the past, the largest barrier was the society because it refused educated and working women. On the other hand, although the there are developments of society, there are much more changes that should be accepted from society. When these areas are solved, the high unemployment rates will be decreased.

The respondents indicated that one of the major problems is that the education system is not in harmony with the need of the private sector. To be exact, females cannot study some majors.

The last type of barriers is that the Saudization Program has resulted in negative impact. One of the reasons for this is because private sector are looking for profits and it does not apply this program in the correct way. In order to enhance the program, the Saudi government should address and solve these problems.

ANOVA test showed that the Saudization Program is not effective. This means that the hypothesis was not rejected. 


\section{Conclusion}

The unemployment rates in females are much higher than the unemployment in males for Saudis. The rates of unemployment of females are higher than males although that the education levels for males and females are close to each other and in some cases the favor is for the females especially for higher education.

From all of the above, it is very clear that the Saudi family and Saudi society has accepted the changes to look more for better and higher education for females and hence, to look for jobs that are associated with the type of education. However, public and private sector and education system have not developed at the same rates to meet the growing needs. For example, the Saudization program is not effective because of the three factors which are the education, private and public sector.

The private sector has not played its role in the process by focusing on the strategic goals in which it absorbs the high unemployment rates. This is because of many reasons such as the low experience of females, the gap between the educational system and the needs for the private sectors and the low effect of Saudization.

\section{Recommendations}

The gap between the education system and the private sector should be closed. This can be done by integrating the education process with the needs of the private sector. The material that is learned should be from the Saudi economical environmental instead of depending on cases from the US or Europe markets.

The privates sector should play a major role in employment especially since the government has sold most of its public sector to the people. There are no taxes in Saudi Arabia and that should encourage the private sector to help more in increasing the employment rates by expanding and competing locally, regionally and internationally.

The government should monitor the whole process and should set boundaries to manage the output of education system and private system based on the strategic goals of the country. 


\section{References}

i. Albahussain, S., 2006. Employability Skills Required by Private Saudi Employers and the Role of Higher Education System in Delivering Them: A Field Study. Journal of Economic and Administrative Sciences.

ii. Al-Munajjed, M., 2010. Women's employment in Saudi Arabia: A major challenge. [Online] Available http://www.saudigazette.com.sa/index.cfm?method=home.regcon\&contentID=2010033067859

iii. Bacon, D., 2005. Labor Needs A Radical Vision. Color Lines Magazine: Race, Action, Culture.

iv. Baki, R., n.d. Gender-segregated Education in Saudi Arabia: its impact on Social Norms the Saudi Labor Market Education policy analysis achieves. [Online] Available at: http://www.cdsi.gov.sa/english/

v. Caudill, J., 2007. The Growth of m-Learning and Growth of mobile Computing: Parallel developments. The international Review of Research in Open and Distributed Learning. [Online]

Available at: http://www.irrodl.org/index.php/irrodl/article/view/348/873

vi. Centerforinquiry.net, 2010. Is Islam Compatible with Democracy and Human Rights?. [Online] Available at: http://www.centerforinquiry.net/isis/islamic viewpoints/is_islam_compatible with democrac $\mathrm{y}$ and human rights/

vii. $\quad$ Cordesman, A., 2003. Saudi Arabia enters the twenty-century. 1 ed. Westport: Praeger.

viii. Crawford, I., 1997. Marketing research and information systems (Marketing and agribusiness Text- 4). 1st ed. Rome: FAO Regional officer for Africa.

ix. Feundi, D., 2010. I discovered the right religion in Islam. [Online] Available http://www.saudigazette.com.sa/index.cfm?method=home.regcon\&contentID=200805307921

x. Fish, M., 2005. The Hazards of Half-measures: Perestroika and Failure of Post-Soviet Democratization. Demokratizatsiya, 13(2), pp. 241-254.

xi. $\quad$ Freedom, B., 2008. Between Gender Equality and Religious Freedom - Islamic Insights. [Online]

Available at: http://islamicinsights.com/news/community-affairs/between-gender-equality-andrelgious-freedom.html

xii. Hamdan, A., 2005. Women and education in Saudi Arabia: Challenges and achievements. International Educational Journal, pp. 44-64.

xiii. John, A., 2005. Open Doors: Foreign Participation in Financial System In developing Countries. Eastern Economic Journal. 
xiv. $\quad$ Kolter, P., 1987. Strategic marketing for nonprofit organizations. 1st ed. Englewood Cliffs, NJ: Prentice Hall.

xv. Madrid, R., 2005. Ideas, Economic Pressures, and Pension Privatization. Latin American Politics\&amp; Society, 47(2).

xvi. Ministry of Higher Education, 2011. Ministry of Higher Education. [Online] Available at: http://www.mohe.gov.sa

xvii. Ministry of Planning, 2010. Saudi Arabia Five-Year Development Plan. [Online] Available at: http://www.mep.gov.sa/

xviii. Ministry of Planning, 2011. Ministry of Planning - Maain Page. [Online] Available at: http://www.mep.gov.sa

xix. MWLUSA, 1995. Gender Equality in Islam. [Online] Available at: http://wwwmwlusa.org/topics/equality/gender.html

xx. Orsburn, C., 2000. Choosing Among a Mailed Questionnaire, Interviews and a Focus Group. 1st ed. s.l.:The Vermont Institutes.

xxi. $\quad$ Rueda, M., 2005. Ready for Takeoff: The Low-Cost Model Comes to Mexico As the Government Prepares to Get Out Of The Airline Business, s.l.: Latine Trade.

xxii. $\quad$ Rugh, W., 2002. Education in Saudi Arabia: Choices and constraints. 1st ed. s.l.:Middle East Policy.

xxiii. Ruiz, J., Michael, M. \& Leipzig, R., 2006. The Impact of E-Learning in Medical Education. [Online] Available at: http://www.med.ufl.edu/oea/opfd/faculty/club med/impact of elearning in medical educati on.pdf

xxiv. Sajini, I., 2004. Effects of WTO on Small \& Medium Enterprises. [Online] Available at: http://www.arabnews.com/node/243217

xxv. Sama.gov.sa, 2010. Forty Sixth Annual Report. The Latest Economic. [Online] Available at: http://www.sama.gov.sa

xxvi. Smith, D., 1987. The Everyday World as Problematic. Toronto: Toronto University Press.

xxvii. Strategic insights, 2004. Can Saudi Arabia Reform its Economy in Time to Head Off Disaster?. [Online]

Available at: http://wwwhsdl.org/?view\&did=444725

xxviii. Trochim, W., 1999. The Research Methods Knowledge Base. 1st ed. s.l.:Atomic Dog Publishing.

xxix. Voluntaryist, 1994. A Definition of Freedom. [Online] Available at: http://www.voluntaryist.com/articles/o70.php

xxx. Watson, J. \& Ryan, J., 2006. Keeping Pace with $K-12$ Online Learning A Review of State-Level Policy and Practice. [Online] Available at: $\quad$ http://www.nacol.org/docs/Keeping\%20Pace\%20with\%20K12\%20Online\%20Learning\%202006.pdf 


\section{Asia Pacific Journal of Contemporary Education and Communication Technology}

ISBN (eBook): 9780994365682 । ISSN : 2205-6181

Year: 2017, Volume: 3, Issue: 2

A P I A R

xxxi. Wto.org, 2005. WTO | 2005 Press Releases - WTO General Council successfully adopts Saudi Arabia's terms of Accession - $\quad$ Press 420. [Online] Available at: http://www.wto.org/english/news e/preso5 e/pr420 e.htm

xxxii. Yamani, M., 1996. Some observations on women in Saudi Arabia: Feminism and Islam: Legal and Literary Perspectives. 1st ed. New York: New York University Press. 


\section{APPENDIX}

Questionnaire

1 - Your age is:

\begin{tabular}{l|l|l} 
[ ] Less than 18 & {$[$ [ ] 19-22 } & [ ] 23-26 \\
\hline [ ] 27-30 & [ ] 31 and more &
\end{tabular}

\section{2 - Your education is:}

\begin{tabular}{l|l|l|l} 
[ ] Elementary & [ ] Middle School & [ ] High School & [ ] Diploma \\
\hline [ ] B.S. Degree & [ ] Master Degree & [ ] PhD &
\end{tabular}

\begin{tabular}{|c|c|c|c|c|c|}
\hline \multirow[t]{10}{*}{$\begin{array}{l}\text { Strongly } \\
\text { Disagree }\end{array}$} & $\begin{array}{l}\text { Disagre } \\
\text { e }\end{array}$ & \multirow[t]{10}{*}{$\begin{array}{c}\text { Not } \\
\text { decided }\end{array}$} & $\underset{\text { e }}{\text { Agre }}$ & \multirow[t]{9}{*}{$\begin{array}{c}\text { Strongly } \\
\text { Agree }\end{array}$} & \\
\hline & & & & & $\begin{array}{l}\text { Transportations is one of the } \\
\text { barriers in education and working }\end{array}$ \\
\hline & & & & & $\begin{array}{l}\text { My family supports me in } \\
\text { education }\end{array}$ \\
\hline & & & & & $\begin{array}{l}\text { The society looks at working } \\
\text { women positively }\end{array}$ \\
\hline & & & & & $\begin{array}{l}\text { There are many good examples of } \\
\text { successful women in their } \\
\text { education }\end{array}$ \\
\hline & & & & & $\begin{array}{l}\text { There is no gap between education } \\
\text { and work requirements }\end{array}$ \\
\hline & & & & & $\begin{array}{l}\text { The major reasons for completing } \\
\text { my education is to find a suitable } \\
\text { job }\end{array}$ \\
\hline & & & & & $\begin{array}{l}\text { There are many types of majors } \\
\text { that I can study }\end{array}$ \\
\hline & & & & & Saudization program is effective \\
\hline & & & & & $\begin{array}{l}\text { The government must issue new } \\
\text { laws regarding employment of } \\
\text { Saudi females }\end{array}$ \\
\hline
\end{tabular}

